\title{
Serologic follow-up of IgG responses against recombinant mycobacterial proteins ML0405, ML2331 and LID-1 in a leprosy hyperendemic area in Venezuela
}

\author{
Elsa $\operatorname{Rada}^{1} /{ }^{+}$, Malcolm S Duthie ${ }^{2}$, Steven G Reed ${ }^{2}$, Nacarid Aranzazu$^{1}$, Jacinto Convit ${ }^{1}$ \\ ${ }^{1}$ Instituto de Biomedicina, Caracas, Venezuela ${ }^{2}$ Infectious Disease Research Institute, Seattle, WA, USA
}

\begin{abstract}
Leprosy is a slowly evolving disease that occurs mainly in adults. In this study, the Mamaria Village, state of Portuguesa was selected because it had one of the highest prevalence rates (13.25\%) of leprosy cases in 1997. Between 1998-2004, 20.2\% of the 89 cases registered in this village were less than 15 years old and $61.8 \%$ were males. Paucibacillary $(P B)$ lesions were the predominant clinical forms identified, although also multibacillary (MB) forms were found. Additionally, $76 \%$ of the patients were bacteriologically negative. At the time of diagnosis, 75\% of the patients presented with grade 0 disabilities, $23 \%$ with grade 1 and $2 \%$ with grade 2 . Serum samples were collected from 18 PB and 15 MB patients, in addition to 14 family contacts, at the beginning and end of treatment. All the groups were re-evaluated during a three-year period (2008-2011). The proteins used for evaluation were ML0405, ML2331 and LID-1. These mycobacterial proteins were highly specific for Mycobacterium leprae and the IgG responses decreased in both MB and PB patients during multidrug treatment. Our results suggest that these antigens could be used as markers for successful treatment of non-reactional lepromatous patients.
\end{abstract}

Key words: leprosy - prevalence - incidence - serology - recombinant proteins

Leprosy is a human communicable, disabling disease produced by Mycobacterium leprae. Among tropical diseases, leprosy is an important cause of permanent physical disabilities. Adults with multibacillary (MB) leprosy are considered to be the main transmitters of the disease. Early diagnosis and treatment prior to the onset of neural damage is the most effective way to prevent disability. Leprosy-induced disabilities are generally the cause of stigma and discrimination in patients (Zulueta 1994).

Over the last two decades, there has been a dramatic reduction in leprosy cases worldwide and all but a few countries have reached the elimination goal established by the World Health Organization (WHO) of $<1$ case $/ 10,000$ inhabitants. Nevertheless, approximately 250,000 new cases are detected annually (Zulueta 1994, WHO 2005). Analysis of incidence and prevalence data shows that despite the identification of new leprosy cases and their inclusion in adequate treatment schemes, transmission still occurs. This finding suggests that contacts with initial lesions or preclinical signs, or leprosy cases not diagnosed opportunely, should also be considered when formulating efforts to reduce transmission (Meima et al. 2004).

Venezuela reached the goal established by the WHO in 1997 to eliminate leprosy as a public health problem (WHO 2000). The detection rate in Venezuela has been

Financial support: Duty Free Americas CA (LOCTI DIA 2-2010), Instituto Biomedicina, IDRI, American Leprosy Mission, Renaissance Health Service Corporation

+Corresponding author: elsa.rada@gmail.com

Received 22 March 2012

Accepted 18 July 2012 decreasing from $16.7 / 10,000$ inhabitants in 1959 to 0.22 in 2010 (Zulueta 1994, Convit et al. 1999, WHO 2005, MPPE/IPASME 2010, MSDS 2010). By 2010, the national prevalence rate had been reduced to $0.34 / 10,000$ inhabitants. Nevertheless, leprosy prevalence rates in the states of Portuguesa, Cojedes and Apure are still higher than those set by the WHO elimination goal (Fig. 1). New cases in these states are predominantly of the MB forms, they are more frequent in males as they age and they are more common in rural areas and disorganised urban areas.

The Institute of Biomedicine has emphasised its leprosy control efforts by maintaining effective surveillance activities in the states where there is still a high incidence. These activities have included the serological evaluation of Mamaría Village, Portuguesa, during the last three years. As reported here, recombinant proteins ML0405, ML2331 and LID-1 can be used for serodiagnosis of leprosy, especially in MB cases (Reece et al. 2006, Duthie et al. 2007, 2008, 2010, 2011).

\section{PATIENTS, MATERIALS AND METHODS}

The area under investigation was Mamaría Village, located at the municipality of Ospino, Aparición Parrish of the state of Portuguesa, Venezuela (Fig. 2). Although it is a dispersed community with an estimated population of 664 inhabitants from 1998-2004, this area is satisfactorily monitored by health authorities. The number of persons examined corresponded to $85 \%$ of the population, which currently remains at nearly 770 inhabitants (Table I).

Patients - Most of the cases diagnosed since 1999 were treated with multidrug therapy (MDT) according to the WHO guidelines, which classifies MB and paucibacillary (PB) cases based on the bacillary load of patients, the number of lesions and the nerves involved. MDT for both adults and children included three anti-mycobacterial 
drugs: dapsone, rifampicin and clofazimine. The treatment periods were six months for PB patients and 12-24 months for MB patients (Rada et al. 1999).

Antigen-specific serum IgG responses - After obtaining informed consent, 47 individuals were selected for the serologic study. The blood was collected, processed on site and kept at $4^{\circ} \mathrm{C}$ until the serum was frozen at $-20^{\circ} \mathrm{C}$. Sera were collected from $18 \mathrm{~PB}$ patients $[9$ male (M) and 9 female (F)] and $15 \mathrm{MB}$ patients (13 M and 2 F). All of the recruited patients were adults with a mean age of $44.49 \pm 0.40$ years. The group of 14 family contacts consisted of six $\mathrm{M}$ and eight $\mathrm{F}$ and their mean age was $41.57 \pm 19$ years.

Serum antibodies to recombinant antigens were determined as described previously (Rada et al. 1999, Duthie et al. 2007, 2008). Anti-recombinant protein detection ELISA was conducted by coating 96-well microtitre plates (Polysorp ${ }^{\circledR}$, Nunc, Rochester, NY) with $1 \mu \mathrm{g} /$ $\mathrm{mL}$ of protein in bicarbonate buffer overnight at $4^{\circ} \mathrm{C}$. We used three recombinant proteins expressed in and purified from Escherichia coli. ML0405 is a conserved 394 aa protein with a $25.3 \mathrm{kDa}$ size, ML2331 is a secreted protein with a $26.5 \mathrm{kDa}$ size and Leprosy Infectious Disease Research Institute Diagnostic-1 (LID-1) is a fusion protein that incorporates certain segments of the previous proteins. The plates were then blocked for $1 \mathrm{~h}$ at room temperature (RT) with phosphate-buffered saline (PBS)/ Tween containing $1 \%$ bovine serum albumin (BSA) on a plate shaker. Serum was added at a 1:200 dilution in 1\% BSA to each well and the plates were incubated at RT for $2 \mathrm{~h}$ with shaking. The plates were washed with PBS/ Tween containing $0.1 \% 4 \mathrm{x}$ and $2 \mathrm{x}$ PBS. Horseradish peroxidase-conjugated anti-human IgG (Fc specific, Sigma, St Louis, MO, USA) was then diluted 1:2500 in PBS/ Tween $0.05 \%$ containing $0.1 \%$ BSA, added to each well and incubated at RT for $1 \mathrm{~h}$ with shaking. After washing, the o-phenylenediamine dihydrochloride (Sigma) enzyme substrate $\left(\mathrm{H}_{2} \mathrm{O}_{2}\right.$ Merck) was added to the plates and incubated at RT for $10 \mathrm{~min}$ in the dark. The reaction was stopped by adding $25 \mu \mathrm{L}$ of $1 \mathrm{~N} \mathrm{H}_{2} \mathrm{SO}_{4}$. The optical density (OD) of each well was obtained using a microplate reader at $492 \mathrm{~nm}$. The cut-off value was calculated by summing the average OD reading obtained for 179 negative control sera (from individuals with no history of leprosy inhabiting the same hyperendemic area) and then adding four times the standard deviation. An OD value of greater than 0.2 was considered positive.

\section{RESULTS}

Between 1998-2004, 89 leprosy cases were registered in the Mamaría Village population and 15 additional cases were registered by 2011 (Table II). Of these cases, $61.8 \%$ were males and $76.4 \%$ were bacteriologically negative such that $\mathrm{PB}$ was the predominant clinical form. In total, $20.2 \%$ of the cases were under 15 years old.

We evaluated the serological responses of this population from 2008 until 2011. During these three years,

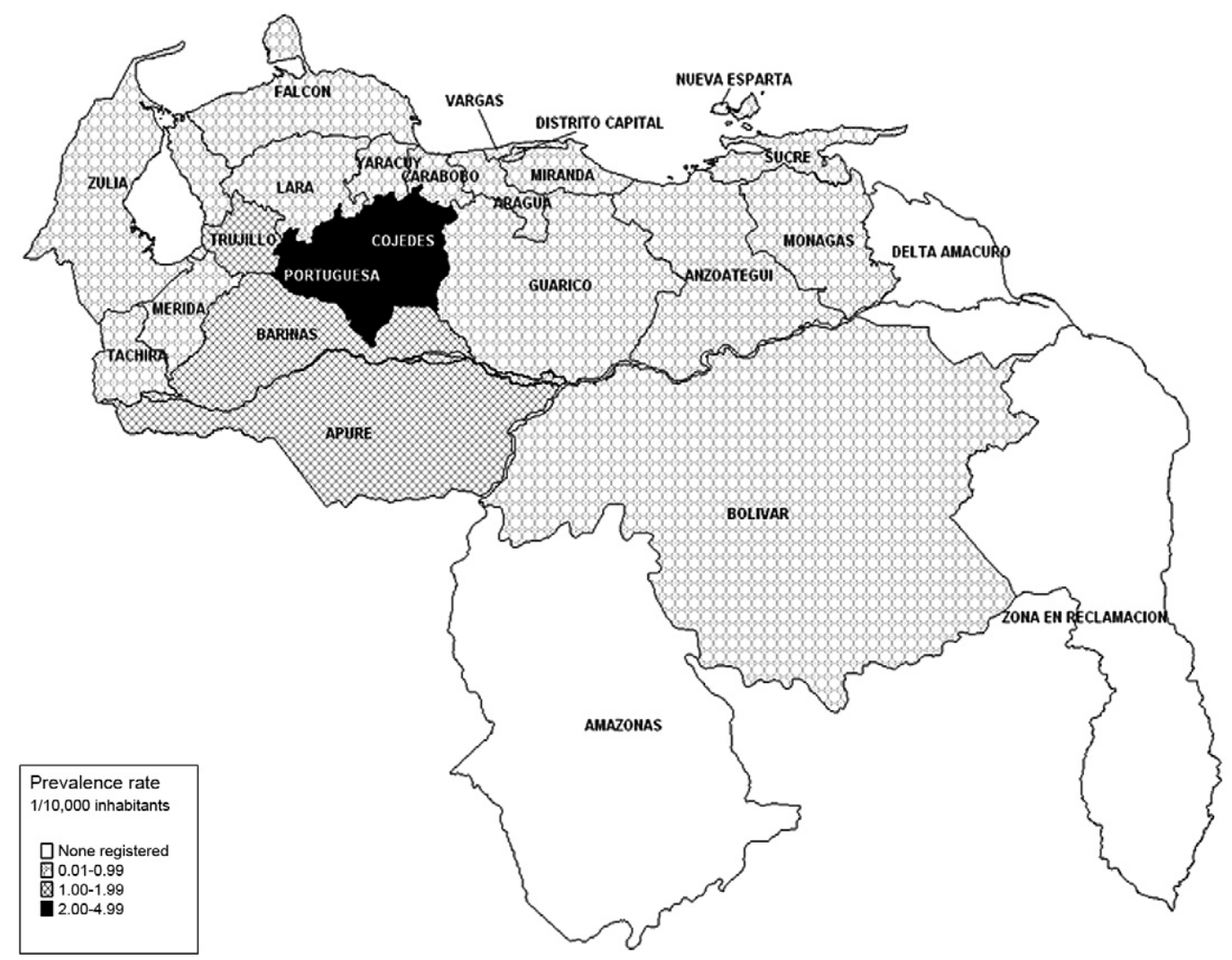

Fig. 1: prevalence of leprosy in Venezuela. Data are presented based upon registration per Federal State, 1999-2008 (MSDS 2010). 
we evaluated the antigen-specific $\operatorname{IgG}$ responses of 47 individuals [33 patients (18 PB and $15 \mathrm{MB}$ ) and 14 family contacts] by collecting multiple blood samples (59 in 2008, 49 in 2009, 32 in 2010 and 167 in 2011) on three different occasions.

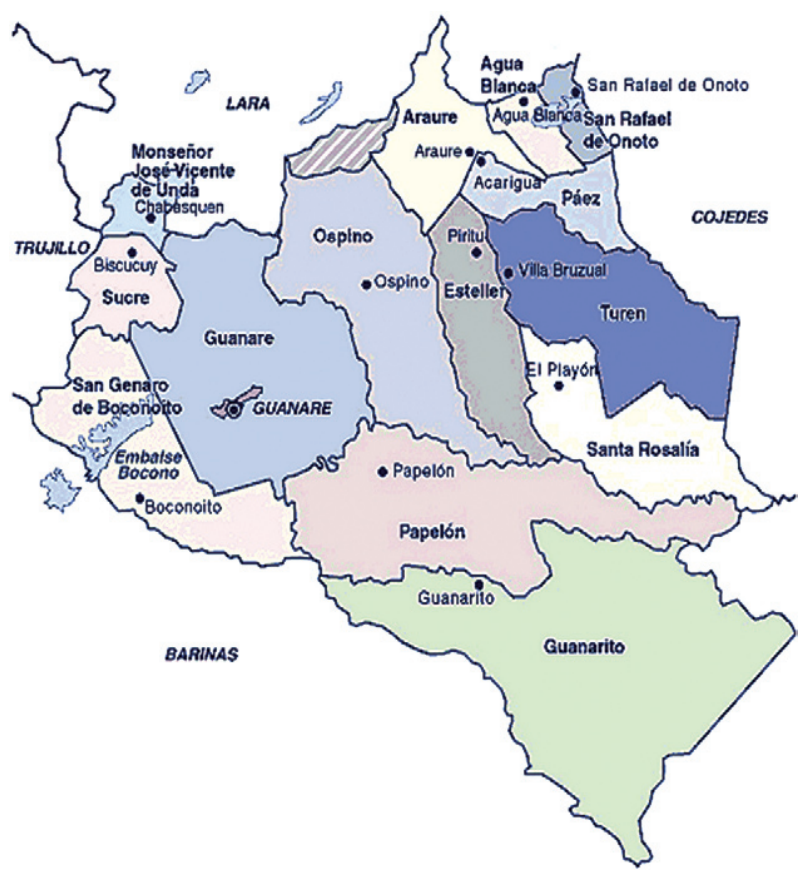

Fig. 2: map of municipalities within state of Portuguesa, Venezuela. The region under surveillance (Mamaría Village) is located in the municipality of Ospino in north-central Portuguesa.

\section{TABLE I}

Leprosy surveillance and detection in various communities, state of Portuguese, Venezuela (1998-2004)

\begin{tabular}{|c|c|c|c|c|}
\hline Community & $\begin{array}{l}\text { General } \\
\text { population } \\
\text { (n) }\end{array}$ & $\begin{array}{c}\text { Examined } \\
\text { population } \\
(\%)\end{array}$ & $\begin{array}{c}\text { Registered } \\
\text { cases } \\
(1998-2004) \\
\text { (n) }\end{array}$ & $\begin{array}{c}\text { Detection } \\
\text { rate } \\
(\%)\end{array}$ \\
\hline Mamaría & 664 & 84.94 & 89 & 13.4 \\
\hline E Pereño & 430 & 91.63 & 18 & 4.1 \\
\hline La Aduana & 695 & 86.33 & 19 & 2.7 \\
\hline El Ruano & 395 & 93.42 & 14 & 3.5 \\
\hline La Chaconera & 195 & 64.10 & 8 & 4.1 \\
\hline La Aguada & 410 & 80.49 & 6 & 1.5 \\
\hline Caño seco & 425 & 80.71 & 11 & 2.5 \\
\hline Garcitas & 370 & 72.97 & 6 & 1.6 \\
\hline Chuspa & 395 & 78.99 & 10 & 2.5 \\
\hline Pirital & 475 & 84.21 & 5 & 1 \\
\hline Paujicito & 645 & 77.98 & 15 & 2.3 \\
\hline Palmarito & 338 & 79.29 & 4 & 1.2 \\
\hline Others (12) & - & - & - & $<0.04$ \\
\hline
\end{tabular}

Of the 15 MB leprosy patients, sera from only two recently diagnosed patients demonstrated positive $\operatorname{IgG}$ values towards the mycobacterial proteins and these responses gradually decreased during the treatment period (C53 and C54 in Fig. 3). These patients were 39 and 47 years old respectively. They were diagnosed at the end of 1999 and were released from treatment in 2002. Another individual who initially belonged to the group of contacts (C99), but was later classified as lepromatous leprosy (LL) patient showed high antibody titres against LID-1 prior to the development of clinical signs. This MB patient was a young $(<16$ years old) family contact and was diagnosed with the LL form in 2010. This individual is currently receiving MDT and his antibodies responses remain high (C99 in Fig. 3). This patient has not completed treatment even though he is now bacteriologically negative.

Of the $18 \mathrm{~PB}$ cases assayed, positive antibody levels towards the recombinant proteins were detected in only one individual (C104 in Fig. 3) and the other 17 sera from cured PB patients were negative. Antibody values were

\section{TABLE II}

Leprosy case detection and presentation during the 1998-2004, Mamaría Village, state of Portuguesa, Venezuela

\begin{tabular}{cccccc}
\hline Year & $\begin{array}{c}\text { Cases } \\
(\mathrm{n})\end{array}$ & $\begin{array}{c}\text { Clinical } \\
\text { form }\end{array}$ & $\begin{array}{c}\text { Cases } \\
\text { (n) }\end{array}$ & $\begin{array}{c}\text { Disability } \\
\text { grade }\end{array}$ & $\begin{array}{c}\text { Cases } \\
\text { (n) }\end{array}$ \\
\hline 1998 & 1 & I & 26 & 0 & 67 \\
1999 & 63 & TT & 20 & 1 & 20 \\
2000 & 6 & BT & 22 & 2 & 2 \\
2001 & 2 & BB & 8 & 3 & 0 \\
2002 & 10 & BL & 8 & - & 89 \\
2003 & 6 & LL & 5 & - & - \\
2004 & 1 & - & 89 & - & - \\
\hline
\end{tabular}

Total 89

BB: borderline borderline; BL: borderline lepromatous; BT: borderline tuberculoid; I: indeterminate; LL: lepromatous leprosy; TT: true tuberculoid.

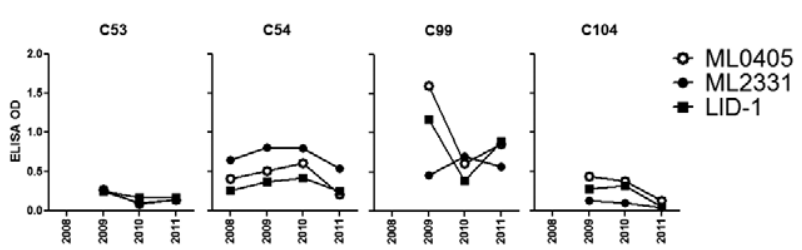

Fig. 3: monitoring of antigen-specific responses over time. Followup analyses were conducted on sera from two adult multibacillary patients (C53 and C54) from a person initially enrolled within the contact group, but who was later classified as lepromatous leprosy patient (C99) and an adult paucibacillary patient (C104). These individuals were IgG positive in their initial sample, even though C53, C54 and C99 were first diagnosed and treated several years earlier. LID: Leprosy Infectious Disease Research Institute Diagnostic-1; OD: optical density. 
always lower in true tuberculoid (TT) patients than in LL patients, and TT patients always showed a faster decrease in antibody levels following treatment compared with LL patients.

\section{DISCUSSION}

Early diagnosis is extremely important for the control of leprosy. It has therefore become increasingly important to identify specific molecular markers that enable an early diagnosis, which results in timely treatment that can potentially interrupt transmission. Although the WHO's goal of elimination was reached in Venezuela 15 years ago (MPPE/IPASME 2010, MSDS 2010), hyperendemic communities remain in the country (Aranzazu et al. 2012). To discover the reason for the continued high prevalence in communities such as Mamaría, it would be useful to identify the actual prevalence in these areas. One of the methods used for prevalence estimation is epidemiological surveillance in addition to annual observations in these areas. Although this approach has allowed us to conduct thorough monitoring of Mamaría, new cases of leprosy are still detected within this population.

In this study, we have identified new leprosy cases within hyperendemic areas in the central plains of Venezuela using recombinant mycobacterial proteins ML0405, ML2331 and LID-1 and we have effectively initiated MDT in these patients. We made similar observations in other geographic areas, such as Santa Cruz, Bolivia (data not shown). This test can easily be performed by the community nurse, which permits an early diagnosis for patients with corresponding benefits. Analysis of the antigen-specific antibody responses of leprosy patients in Mamaría confirmed a differential antibody response between MB and $\mathrm{PB}$ patients and similar results have been found in other Venezuelan communities (Duthie et al. 2011, Aranzazu et al. 2012). The antibody response was elevated in MB patients, which correlated with increased bacterial loads. These results correspond with previous results from other investigations, where these recombinant antigens have been useful as diagnostic markers of leprosy (Reece et al. 2006, Duthie et al. 2007, 2008, 2010, 2011).

Because of the incomplete development of their immune system and their close contact with family members, children living in leprosy-endemic areas are at a higher risk of developing the disease than adults (Grover et al. 2005, Lana et al. 2007, di Martino Ortiz et al. 2011). During the last 11 years, 599 leprosy cases have been reported in children younger than 14 years old living in Venezuela (mean age of 11 years) and Portuguesa has reported the highest number of these incidences (MSDS 2010). Within Mamaría, nearly one quarter of cases occurred in people under 20 years of age. We have been able to detect leprosy cases within adults and children using the ML0405, ML2331 and LID-1 proteins, including cases in which we have detected high IgG levels (data not shown). The frequency of leprosy in children is an indicator of the prevalence of the disease in the general population and its detection helps to reveal the natural history of the disease, its incubation period and the source.

The results obtained in previous studies of leprosy patients have demonstrated a strong decrease in IgG lev- els against various mycobacterial proteins (Mt $70 \mathrm{kDa}$, $\mathrm{Mb} 65 \mathrm{kDa}, \mathrm{Ml} 10 \mathrm{kDa}$ and complete $M$. leprae proteins) following treatment for the disease. Following MDT, IgG antibody responses decreased much faster in $\mathrm{PB}$ patients (1 year) than in MB patients (2 years). However, most of these proteins were not specific markers and some of the heat shock proteins presented cross reactivity with their human homologs, as well as in contacts who had previously been sensitised towards $M$. leprae (Launois et al. 1994, Rada et al. 1999). Hyperendemic areas were kept under permanent surveillance and 63 new cases were detected in 2009 through active house-to-house searches for case activities. Similar trends were also observed in other communities (Aranzazu et al. 2012). In this study, we identified new leprosy cases within hyper-endemic areas in the central plains of Venezuela using ELISA with recombinant mycobacterial proteins ML0405, ML2331 and LID-1. This easily conducted test permits an early diagnosis, with the added benefit of prompt MDT initiation (Duthie et al. 2011). To fully contribute to the antileprosy campaign, it is important to understand the actual leprosy situation in Venezuela. The active search for leprosy patients using an immunological tool will result in the early diagnosis of leprosy cases and will hopefully decrease the incidence in hyperendemic areas, which have remained relatively stable.

In conclusion, new leprosy cases were detected in a hyper-endemic region using the recombinant mycobacterial proteins ML0405, ML2331 and LID-1. The results indicate that the LID-1 antigen can be used as an immunological tool for the diagnosis of leprosy. Our data also indicate that antibody levels decrease after MDT and thus that the LID-1 protein can be used as an indicator of successful treatment.

\section{ACKNOWLEDGEMENTS}

To Vestalia Rodríguez, José Morales and Antonia Mulato, for excellent technical assistance.

\section{REFERENCES}

Aranzazu N, Parra JJ, Cardenas M, Rada E, Zerpa O 2012. Cojedes: a leprosy hyperendemic state. Int J Dermatol 51: 186-194.

Convit J, Avilán R, Díaz D, Ulrich M, Quiroga R, Aranzazu N, Borges R, Pinardi M 1999. Control de la lepra en Venezuela después de más de 5 décadas de desarrollo. Rev Leprol 21: 145-162.

di Martino Ortiz B, Masi MR, Knopfelmacher O, de Lezcano LB 2011. Childhood leprosy: report of a case. Dermatol Online J 17: 13.

Duthie MS, Goto W, Ireton GC, Reece ST, Cardoso LP, Martelli CM 2007. Use of protein antigens for early serological diagnosis of leprosy. Clin Vacc Immunol 14: 1400-1408.

Duthie MS, Hay MN, Morales CZ, Carter L, Mohamath R, Ito L 2010. Rational design and evaluation of a multiepitope chimeric fusion protein with the potential for leprosy diagnosis. Clin Vaccine Immunol 17: 298-303.

Duthie MS, Hay MN, Rada EM, Convit J, Ito L, Oyafuso LK, Manini MI 2011. Specific IgG antibody responses may be used to monitor leprosy treated efficacy and as recurrence prognostic markers. Eur J Cli Microbiol Infect Dis 30: 1257-1265.

Duthie MS, Ireton GC, Kanaujia GV, Goto W, Liang H, Bhatia A 2008. Selection of antigens and development of prototype tests for pointof-care leprosy diagnosis. Clin Vaccine Immunol 15: 1590-1597. 
Grover C, Nanda S, Garg VK, Reddy BS 2005. An epidemiologic study of childhood leprosy from Delhi. Pediatr Dermatol 22: 489-490.

Lana FC, Amaral EP, Lanza FM, Lima PL, de Carvalho AC, Diniz LG 2007. Hansen's disease in children under fifteen years-old in Jequitinhonha Valley, Minas Gerais, Brazil. Rev Bras Enferm 60: 696-700.

Launois P, Niang MN, Drowart A, Van Vooren JP, Sarthou JL, Lalu T, Millan J, Huygen K 1994. IgG response to purified 65 and $70 \mathrm{kDa}$ mycobacterial heat shock proteins and to antigen 85 in leprosy. Int J Lepr 62: 48-54.

Meima A, Richardus JH, Habbema JD 2004. Trends in leprosy case detection worldwide since 1985. Lepr Rev 75: 19-33.

MPPE/IPASME - Intituto de Previsión y Asistencia Social para el personal del Ministerio de Educación/Ministerio del Poder Popular para la Educación 2010. Venezuela logró eliminar la lepra como problema de salud pública. Available from: ipasme. gob.ve/index.
MSDS - Ministerio Salud Desarollo Social 2010. Instituto de Biomedicina. Estadísticas de la Lepra en Venezuela. Departamento de Informática. Caracas, Venezuela 378pp.

Rada E, Aranzazu N, Ulrich M, Convit J 1999. Serologic response to mycobacterial proteins in Hansen's patients during multidrug treatment. Int J Lepr 67: 414-421.

Reece ST, Ireton G, Mohamath R, Guderian J, Goto W, Gelbert 2006. ML0405 and ML2331 are antigens of Mycobacterium leprae with potential for diagnosis of leprosy. Clin Vacc Immunol 13: 333-340.

WHO - World Health Organization 2000. The final push towards. Elimination of leprosy. Strategic plan 2000-2005, WHO, Geneva, $12 \mathrm{pp}$.

WHO - World Health Organization 2005 Estrategia mundial para aliviar la carga de la lepra y sostener las actividades de control de la enfermedad. Período del plan: 2006-2010. Available from: who.int/lep/en/.

Zulueta A 1994. Evolución histórica, epidemiológica y medidas de control. Dermatol Venezol 32: 181-190. 